\begin{tabular}{lcr}
\hline \multicolumn{3}{c}{ ANNALES } \\
UNIVERSITATIS MARIAE CURIE-SKŁODOWSKA & \\
LOL. LXXI, 1 & LELIN - POLONIA & \\
\hline
\end{tabular}

\title{
Flotation of copper-bearing carbonaceous shale in the presence of amine type frothers
}

\author{
Michal Stodulski and Jan Drzymala* \\ Wroclaw University of Technology, Mineral Processing Research Group, \\ Wybrzeze Wyspianskiego 27, 50-370 Wroclaw, Poland, \\ "e-mail:jan.drzymala@pwr.edu.pl
}

\begin{abstract}
Hexylamine, chloro-derivative of propylamine, and ammonium chloride were used for flotation of Permian carbonaceous copper-bearing shale from the Legnica-Glogow Copper Basin region in SW Poland. It was confirmed that naturally hydrophobic shale, known as Kupferschiefer, can be made floatable by application of short chain amines as frothers. It was also established that the short chain amine chloro-derivatives as well as salmiac, the first member of the amine family, can be used as a frother for flotation of the investigated shale sample. It results from the paper that the investigated amine frothers work similarly. This conclusion is reached when the flotation results are compared using frother concentration divided by the critical coalescence concentration, that is concentration at which mutual coalescence of air bubbles is prevented.
\end{abstract}

Keywords: flotation frothers, copper shale, critical coalescence concentration

\section{INTRODUCTION}

Copper-bearing shale, also called European Permian black shale or Kupferschiefier $[1,2]$ is a part the copper ore currently mined in Poland in the Legnica-Glogow Copper Basin area [3]. The shale forms a layer from a few centimeter to $4 \mathrm{~m}$ thick, which was formed approximately 250 
million years ago [4] and now covers roughly the Baltic Sea and North Sea countries areas, that is Northwestern Poland, Germany, part of Lithuania and East Great Britain.

Locally shale is enriched in base metals such as $\mathrm{Cu}, \mathrm{Pb}, \mathrm{Zn}, \mathrm{Co}, \mathrm{Ni}$ and some precious metals including $\mathrm{Ag}$ and $\mathrm{Au}[5,6]$. The shale contains metals, mostly in the form of sulfides. Other components of shale are carbonaceous matter, carbonates, quartz and clay minerals.

Extraction of the base metals from the ore is performed by a series of operations including mining, size reduction, flotation, dewatering, smelting, and final purification. Currently, flotation involves application of tio-chelating reagents including xanthates, aerofloats, carbamininas as collectors, as well as frothers in the form of alcohols and their derivatives [7]. It was established many years ago that copper-bearing shale does not float naturally, that is the absence of flotation reagents [8] even though the shale is hydrophobic [9]. Its hydrophobicity, expressed by the socalled contact angle, is about $40^{\circ}$. The flotation of shale can be induced by using only frothers [10]. Now, it is known that shale flotation is possible in the presence of such frothers as aliphatic alcohols [11], etoxylated [12] and propoxylated [13] alcohols (also called ethers), $\gamma$-valerolactone [14], pyridine [11], hexylamine $[15,16]$ and other frothers including poly(ethylene glycol) alkyl ethers [17]. In this paper flotation of copperbearing shale using two amine type reagents and salmiac $\left(\mathrm{NH}_{4} \mathrm{Cl}\right)$, the first member of the aliphatic amines family, as flotation frothers in collectorless flotation was investigated.

\section{EXPERIMENTAL}

\subsection{Shale}

The shale sample was obtained from KGHM Polska Miedz S.A. It originated from the Rudna region. Its full characteristics were presented by Bakalarz [18]. The mineral composition of shale used in this work is

given in Table 1. The shale sample was crushed with a hammer and next ground manually in a ceramic mortar. Next, the sample was sieved through a $0.1 \mathrm{~mm}$ screen until all the material was below $0.1 \mathrm{~mm}$ in size. 
Table 1. Mineral composition of investigated shale [18].

\begin{tabular}{lc}
\hline Mineral & Distribution, \% \\
\hline Bornite & 14.80 \\
Quartz & 10.11 \\
Dolomite & 7.55 \\
Feldspars & 6.39 \\
Pyrite & 1.82 \\
Chalkopyrite & 0.89 \\
Galena & 0.48 \\
Cubanite & 0.29 \\
Sphalerite & 0.16 \\
Chalcocite+digenite & 0.06 \\
Tennantite & 0.02 \\
Covellite & 0.01 \\
Other aluminosilicates & 49.34 \\
Calcite, apatite, limonite etc. & 8.08 \\
\hline
\end{tabular}

\subsection{Reagents}

Hexylamine $\left(\mathrm{C}_{6} \mathrm{H}_{13} \mathrm{NH}_{2}\right)$ was purchased from the Sigma-Aldrich company, 3-chloropropyloamine hydrochloride $\left(\mathrm{Cl}-\mathrm{C}_{3} \mathrm{H}_{6}-\mathrm{NH}_{2} \cdot \mathrm{HCl}\right)$ was supplied by Aldrich, while ammonium chloride (salmiac, $\mathrm{NH}_{4} \mathrm{Cl}$, $\mathrm{H}-\mathrm{NH}_{2} \cdot \mathrm{HCl}$ ), was obtained from Chempur. All chemical were used without any further purification.

\subsection{Flotation}

Flotation experiments were conducted by using a Mechanobr type subareated laboratory flotation machine. The total volume of the flotation cell was $250 \mathrm{~cm}^{3}$, the amount of solids used in the experiment was $70 \mathrm{~g}$ and the volume of aqueous solution in flotation was $150 \mathrm{~cm}^{3}$. In the case of flotation of shale with hexylamine, the solids were inserted into the 


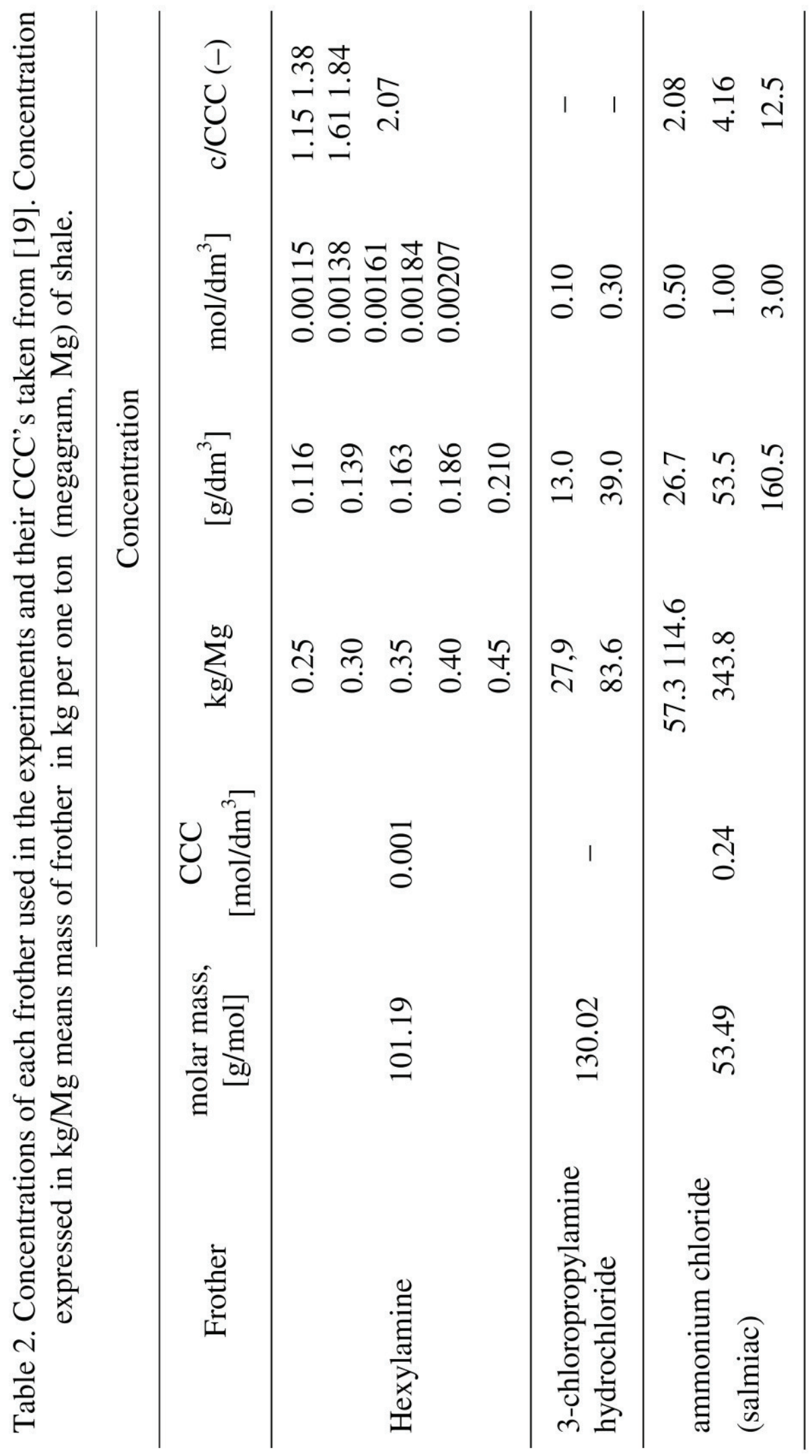


flotation cell, predetermined amount of water was added, agitated for 1 minute and next appropriate amount of $0.1 \%$ hexylamine aqueous solution added (in the case of flotation at $250 \mathrm{~g} / \mathrm{Mg}$ of hexylamine the dose was $17.5 \mathrm{~cm}^{3}$ ). The concentration expressed in $\mathrm{kg} / \mathrm{Mg}$ means mass of frother in $\mathrm{kg}$ per one ton (megagram, $\mathrm{Mg}$ ) of shale The suspension was agitated for 2 minutes before air was admitted to start flotation. In the case of flotation with chloropropylamine hydrochloride, the solids were mixed with aqueous solution of the reagent (either 0.1 and $0.3 \mathrm{M}$ ) without adding any water. In the course of flotation the pulp level was kept constant by adding chloropropylamine hydrochloride solution (ether 0.1 or $0.3 \mathrm{M}$ ). The same procedure, as for chloropropylamine hydrochloride, was applied for salmiac, except that the used solutions were $0.5,1.0$ and $3.0 \mathrm{M}$. The flotation products were collected after 2 (concentrate 1), 5 (concentrate 2) and 8 (concentrate 3 ) minutes of flotation. The flotation products were next dewatered with a Büchner funnel, rinsed with distilled water to remove traces of frother from the sample and finally dried in a drier.

Table 2 shows the concentration of each frother used in the experiments and their frothing properties in the form of the so-called critical coalescence concentration (CCC) [19]. The CCC is the frother concentration at which the mutual coalescence of gas bubbles, which are immersed in water, is prevented.

\subsection{Contact angle}

The contact angle was measured utilizing the sessile drop method by using a Phoenix 300 SEO goniometer. It was equipped with a macro objective allowing for a high quality image of drops and a micro-syringe for formation of individual drop of aqueous solutions. The pictures were transferred to a computer and next, using the IMAGEJ software, the values of contact angle were calculated. The contact angles were calculated from the geometry of the drop.

\section{RESULTS AND DISCUSSION}

The conducted experiments revealed that the investigated shale can be floated in the used laboratory flotation machine with all the three applied reagents, that is hexylamine, chloro-derivative of propylamine and salmiac (Fig. 1). 


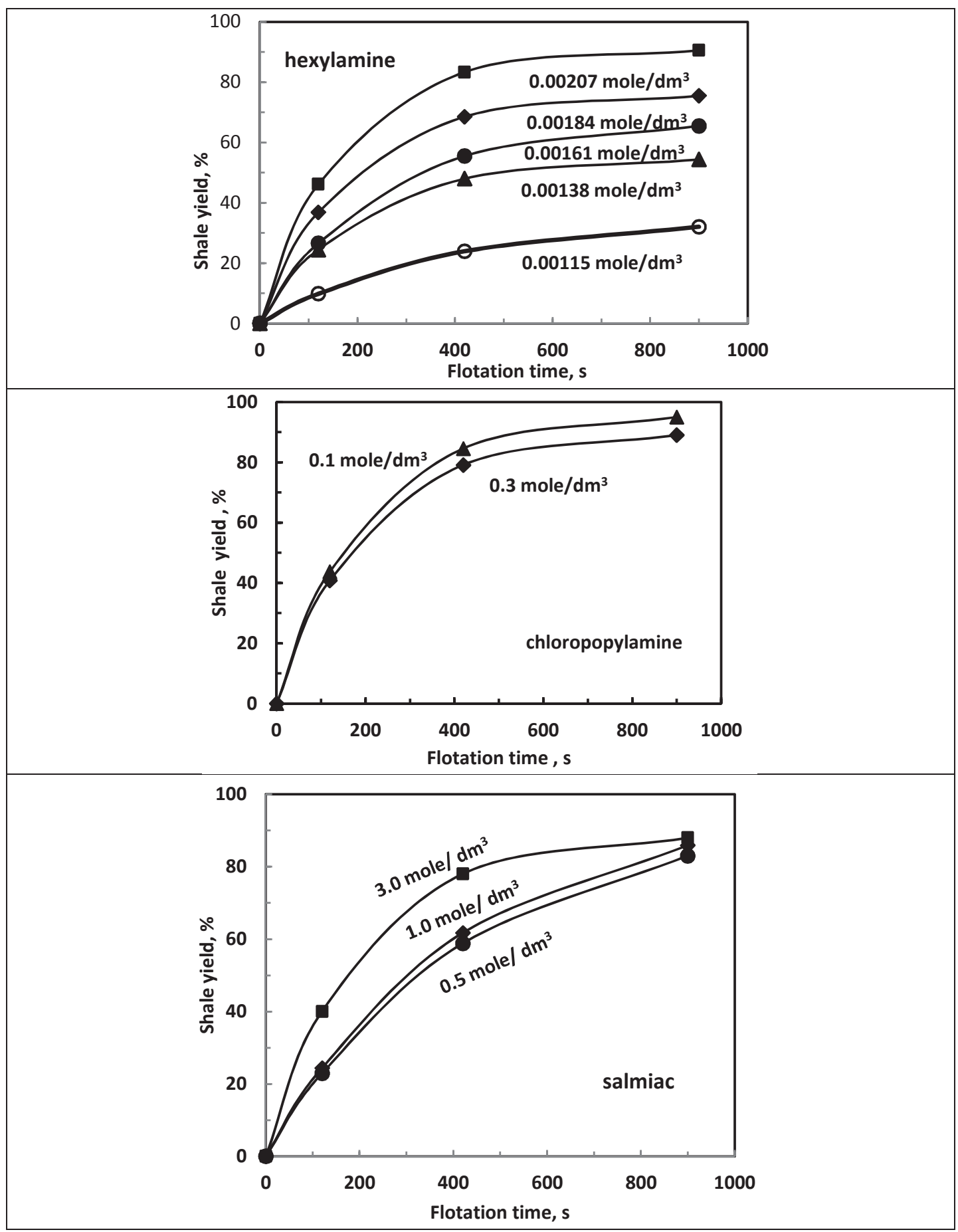

Fig. 1. Flotation of shale in the presence of a) hexylamine, b) 3-chloropropylamine hydrochloride, c) salmiac

The presented in Fig. 1 results for hexylamine agree well with the previous flotation data for the same system investigated by Szajowska et 
al. [15]. The data for salmiac and 3-chlorporpylamine hydrochloride are new since these flotation systems have not been so far investigated.

There is a difference in flotation results between the applied reagents because a complete flotation of shale is possible only at a characteristic reagent concentration (Fig. 1). Figure 1 also shows, that after about 15 min of flotation the shale yield reaches a plateau level. The term shale yield means the mass of shale, expressed in percent, transferred by flotation from the flotation feed to the flotation concentrate.

To compare flotation results of different frothers the same concentration unit should be used. However, it is not clear whether to use the concentration of frother in aqueous solution expressed in mole $/ \mathrm{dm}^{3}$ (Fig. 2a), g/mole (Fig.2b) or as mass of frother in grams per mass of shale in megagrams $(\mathrm{g} / \mathrm{Mg})$ (Fig. 2c). It was previously suggested that the best approach is comparing flotation results taking into account a relative concentration in the form of frother concentration divided by the critical coalescence of frother, both expressed in the same units $[17,20]$. The CCC for salmiac is $0.24 \mathrm{~mole} / \mathrm{dm}^{3}$, while for hexylamine is 0.001 mole/ $\mathrm{dm}^{3}$ [19]. No CCC is available for chloro-propylamine. Plotting flotation yield of shale after 15 minutes of flotation as a function of frother relative concentration (c/CCC) for salmiac and hexylamine (Fig. 2d) reveals that their behavior is similar.

There could be some doubts about amine acting in flotation solely as a frother. Long chain amines are known as flotation collectors rendering the surface of particles subjected to flotation hydrophobic [21]. Particles hydrophobicity diminishes with decreasing aliphatic chain length of the applied amine until it reaches the natural hydrophobicity of the particle. In the case of the investigated here hexylamine, the hydrophobicity of shale was almost unchanged. Table 3 shows that contact of shale in water was $43^{\circ}$ while in the hexylamine solutions was slightly increasing with the amine concentration to about $47^{\circ}$.

Also it is known that salts do not change hydrophobicity of materials [22]. Therefore, all the three reagents used in this investigation should be treated as frothers, which make shale floatable. 


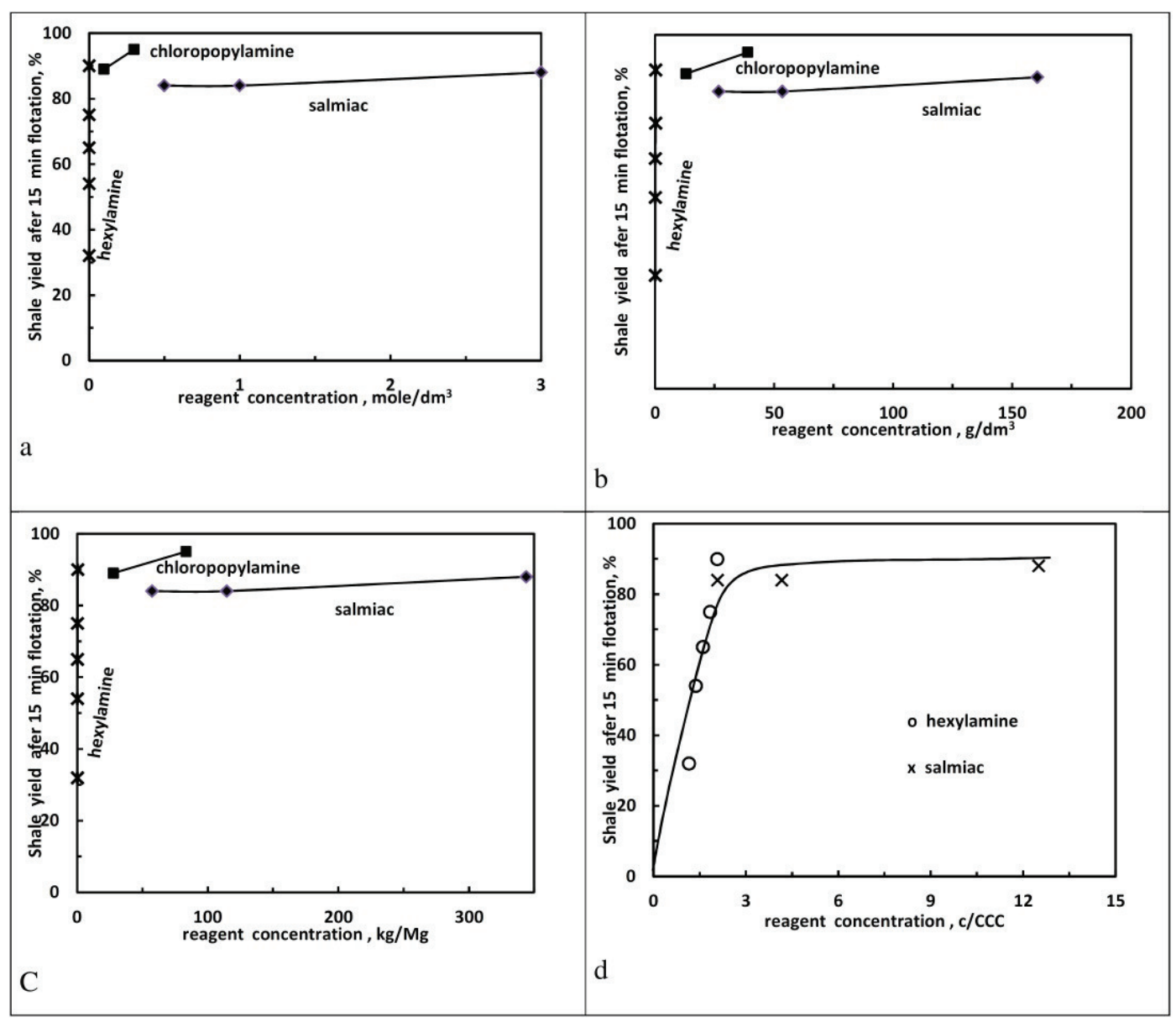

Fig. 2. Comparison of flotation results for investigated frothing reagents with frother concentration expressed in different units a) mole/ $\left./ \mathrm{dm}^{3}, \mathrm{~b}\right) \mathrm{g} / \mathrm{dm}^{3}$, c) $\mathrm{kg} /$ megagram of shale, d) c/CCC.

Table 3. Contact angle measurements.

\begin{tabular}{cccc} 
& \multicolumn{3}{c}{ Contact angle, degree } \\
\cline { 2 - 4 } Exp. No. & distilled water & $\begin{array}{c}\text { hexylamine } \\
\left(1.15 \mathrm{mmole}_{\mathrm{dm}}{ }^{3}\right)\end{array}$ & $\begin{array}{c}\text { hexylamine } \\
\left(2.07 \mathrm{mmole} / \mathrm{dm}^{3}\right)\end{array}$ \\
\hline 1 & 48.8 & 48.6 & 44.3 \\
2 & 38.3 & 44.4 & 48.5 \\
3 & 41.3 & 44.8 & 45.5 \\
4 & 41.9 & 45.2 & 49.2 \\
5 & 42.0 & 45.7 & 47.9 \\
\hline average & 42.5 & 45.7 & 47.1 \\
\hline
\end{tabular}




\section{CONCLUSIONS}

Used in this work hexylamine, chloro-derivative of propylamine, and ammonium chloride can be applied as frothers for flotation of copperbearing carbonaceous shale. The dose of frother needed to float shale is different for the applied regents and decreases with the increase of the length of the chain of amine. This agrees with the observation of Fuerstenau et al. [21]. It was also established that frothers work similarly if comparison of flotation results is made at a relative concentration of the frother. The relative concentration of the frother was expressed as the concentration of frother divided by its CCC, both expressed in the same units. The CCC is the concentration of frother at which mutual coalescence of air bubbles is prevented. Thus, the naturally hydrophobic shale [23], known as Kupferschiefer, can be made floatable by application of amine type frothers including aliphatic short chain amines, their chloro-derivatives, and ammonium chloride as the first member of the amine family.

\section{REFERENCES}

[1] K. H. Wedepohl, Geological Quarterly, 38(4), 623, (1994).

[2] S. Kutschke, A.G. Guezennec, S. Hedrich, A. Schippers, G. Borg, A. Kamradt, J. Gouin, F. Giebner, S. Schopf, M. Schlomann, A. Rahfeld, J. Gutzmer, P. D'Hugues, K. Pollmann, S. Dirlich, F. Bodenan, Minerals Engineering, 2014, in press.

[3] Monografia KGHM Polska Miedź S.A., 2007, A. Piestrzyński (editor-in-chief), A. Banaszak, M. Zaleska-Kuczmierczyk (Eds), $2^{\text {nd }}$ Issue, Lubin: KGHM CUPRUM Sp. z o. o CBR, Wrocław, (2007).

[4] D. J. Vaughan, M. Sweeney, F. R. Diedel, C. Haranczyk, Economic Geology, 84, 1003, (1989).

[5] J. Konstantynowicz-Zielińska, Rudy i Metale Nieżelazne, 35(5-6), 128, (1990).

[6] Z. Konopacka, K.D. Zagożdżon, w: Łupek miedzionośny, J. Drzymała, P. B. Kowalczuk (Esd.), Wydział Geoinżynierii, Górnictwa i Geologii PWr, Wroclaw, (2014), p. 7.

[7] J. Drzymala, Mineral Processing. Foundations of theory and practice of minerallurgy, Oficyna Wyd. PWr., Wroclaw, 2007, 507 pages, http://www.dbc.wroc.pl/dlibra/ docmetadata?id=2070\&from =publication. 
[8] J. Drzymala, J.Bigosinski, Mineralogia Polonica, 26(1), 63, (1995).

[9] P. Bednarek, P. B. Kowalczuk, [in:] Łupek miedzionośny, J. Drzymała, P. B. Kowalczuk (Eds.), Wydział Geoinżynierii, Górnictwa i Geologii PWr, Wroclaw (2014), p. 51.

[10] A. Konieczny, W. Pawlos, M. Krzeminska, R. Kaleta, P. Kurzydlo, Physicochem. Probl. Miner. Process. 49(1), 189, ( 2013).

[11] K. Witecki, M. Duchnowska, P.B. Kowalczuk, [in:] Łupek miedzionośny, J. Drzymała, P. B. Kowalczuk (Eds.), Wydział Geoinżynierii, Górnictwa i Geologii PWr, Wroclaw, (2014), p 83.

[12] D. Szyszka, P. Pązik, A. Zwierzchowska, A, [in:] Łupek miedzionośny, J. Drzymała, P. B. Kowalczuk (Eds.), Wydział Geoinżynierii, Górnictwa i Geologii PWr, Wroclaw, (2014), p. 103.

[13] D. Szyszka, M. Siwiak, P.B. Kowalczuk, [in:] Łupek miedzionośny, J. Drzymała, P. B. Kowalczuk (Eds.), Wydział Geoinżynierii, Górnictwa i Geologii PWr, Wroclaw, (2014), p. 65.

[14] J. Cichański, J. Drzymała, [in:] Łupek miedzionośny, J. Drzymała, P. B. Kowalczuk (Eds.), Wydział Geoinżynierii, Górnictwa i Geologii PWr, Wroclaw, (2014), p. 99.

[15] J. Szajowska, K. Wejman, P.B. Kowalczuk, [in:] Łupek miedzionośny, J. Drzymała, P.B. Kowalczuk (Eds.), Wydział Geoinżynierii, Górnictwa i Geologii PWr, Wrocław (2014), p. 91.

[16] P.B. Kowalczuk, D. Mroczko, D., J. Drzymala, Physicochem. Probl. Miner. Process., 51(2), 547, (2015).

[17] P.B. Kowalczuk, B. Buluc, B., O. Sahbaz, J. Drzymala, J. Physicochem. Probl. Miner. Process., 50(2), 835, (2014).

[18] A. Bakalarz, [in:] Łupek miedzionośny, J. Drzymała, P. B. Kowalczuk (Eds.), Wydział Geoinżynierii, Górnictwa i Geologii PWr, Wroclaw (2014), p/ 13.

[19] D. Szyszka, unpublished data.

[20] M. Peng, J. Drzymała, [in:] Łupek miedzionośny, J. Drzymała, P. B. Kowalczuk (Eds.), Wydział Geoinżynierii, Górnictwa i Geologii PWr, Wroclaw, (2014), p. 71.

[21] D. Fuerstenau, T.W. Healy, P. Somasundaran, Trans. AIME, 229, 321, (1964).

[22] J. Laskowski, J, Iskra, Trans. IMM, London, Sec. C., 79, C6, (1970).

[23] J. Drzymała, [in:] Łupek miedzionośny, J. Drzymała, P. B. Kowalczuk (Eds.), Wydział Geoinżynierii, Górnictwa i Geologii PWr, Wroclaw (2014), p. 77. 